\title{
Erratum: New constraints on the thickness of the Semail ophiolite in the Northern Emirates
}

\author{
Charles Naville • Martine Ancel • Paul Andriessen • \\ Patrice Ricarte • François Roure
}

Published online: 11 January 2011

(C) Saudi Society for Geosciences 2011

Erratum to: Arab J Geosci (2010) 3:459-475

DOI 10.1007/s12517-010-0237-8

Unfortunately the word "constraints" in the original title was wrongly spelled.

During typesetting Figure $3 \mathrm{a}$ was unfortunately reduced to a size that made the labeling illegible.

Please find the original figure here:

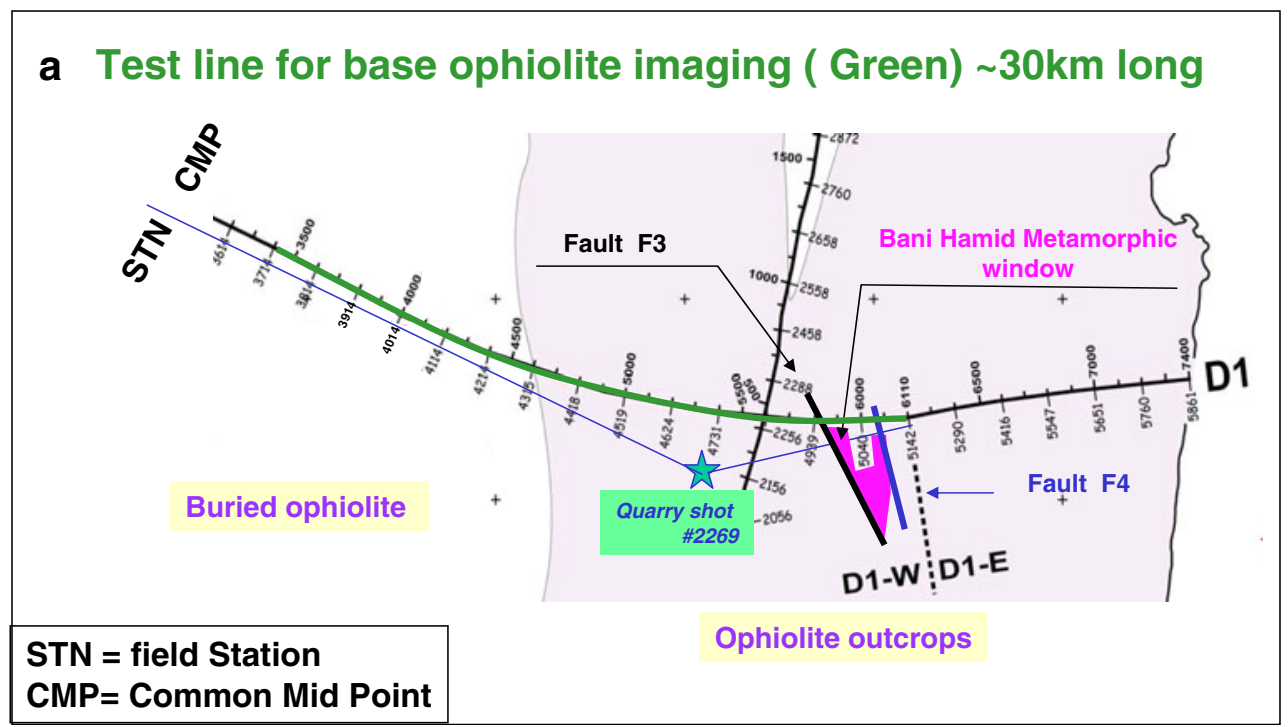

The online version of the original article can be found at http://dx.doi. org/10.1007/s12517-010-0237-8.

C. Naville $(\varangle) \cdot$ M. Ancel $\cdot$ P. Ricarte $\cdot$ F. Roure

Geology-Geochemistry-Geophysics, IFP Energies nouvelles,

1 et 4, Avenue de Bois-Preau - BP 311,

92852, Rueil Malmaison Cedex, France

e-mail: Charles.Naville@ifpenergiesnouvelles.fr

M. Ancel

e-mail: Martine.ANCEL@ifpenergiesnouvelles.fr
P. Ricarte

e-mail: Patice.Ricarte@ifpenergiesnouvelles.fr

F. Roure

e-mail: Francois.Roure@ifpenergiesnouvelles.fr

P. Andriessen · F. Roure

Faculty of Earth and Life Sciences, VU University, de Boelelaan 1085,

1081, Amsterdam, The Netherlands 